\title{
Do traditional land rehabilitation processes improve habitat quality and function? Life-history traits of ground beetles (Coleoptera, Carabidae) say no.
}

\author{
TOMASZ SKALSKI ${ }^{1}$ \\ RENATA KĘDZIOR ${ }^{2}$ \\ ARTUR SZWALEC 2 \\ PAWEŁ MUNDAŁA ${ }^{2}$ \\ ${ }^{1}$ Department of Entomology, Institute of Zoology \\ Jagiellonian University, ul. Gronostajowa 9 \\ 30-387 Kraków, tomasz.skalski@uj.edu.pl \\ 2 Department of Ecology, Climatology and \\ Air Protection, Agricultural University of Krakow \\ al. A. Mickiewicza 24/28, 30-059 Kraków \\ r.kedzior@ur.krakow.pl

\section{Correspondence:} \\ Tomasz Skalski \\ E-mail: tomasz.skalski@uj.edu.pl
}

Key words: forest restoration, slag heap, Carabidae, functional traits
Received January 12, 2016.

Revised June 10, 2016.

Accepted June 27, 2016

\begin{abstract}
Background and purpose: In the thermal power station industry, waste is deposited on various types of slag heaps, which should be rehabilitated in order to restore ecosystem functioning. Traditional restoration processes focus mainly on recreating a tree zone, while the function of the soil is neglected. The aim of the project was to estimate the influence of land restoration (traditional tree plantation without rehabilitation of the soil layer) on the life traits of ground beetles in slag deposition areas.
\end{abstract}

Materials and methods: In a habitat restoration experiment, five sites sampled using pitfall traps were established in a rehabilitated forest and an untreated meadow, with the same number of traps set up on reference forest and meadow sites. Carabid beetles were classified into five categories according to life-history traits: body size, feeding strategy, breeding type, wing development and habitat preferences.

Results and conclusions: Non-metric multidimensional scaling indicated that twenty years of rehabilitation processes had had no effect on the species composition of slag heap forest carabid assemblages. These forest assemblages consisted mainly of species having broad ecological requirements, which are characteristic of initial succession. The most notable feature of the distribution of carabid life-history traits on the slag heap is the reduction in abundances of such groups as large and small predatory specialists having an autumn breeding type of reproduction, with limited dispersal abilities, and preferring forests. The results showed that restoration involving only tree plantation does not guarantee the successful recreation of a functioning and stable ecosystem, as the ecosystem remains in the initial stage.

\section{INTRODUCTION}

The main objective of ecosystem restoration measures is to attempt 1 to restore the natural level of species diversity in areas degraded by human activity (1). This is particularly important in the case of postindustrial land, where physical deformations of the surface of the land in the form of pits or waste heaps lead to dramatic changes in both abiotic and biotic elements of the environment (2). Due to the large surface occupied by these areas worldwide, they are subjected to a variety of reclamation techniques aimed at restoring biological diversity $(3$, 4). Most reclamation measures focus on restoring forest ecosystems by planting trees in an appropriate sequence for a given region (Forestry Reclamation Approach) (5). Such measures, however, which neglect 
restoration of the soil fauna diversity responsible for proper circulation of elements $(2,6)$, do not allow for rapid colonization of the degraded land.

The rate of secondary succession and recolonization of post-industrial areas is strongly dependent on many factors, including the nature of the degraded area, the type of soil or substrate, availability of light, moisture conditions, and availability of resources from the surrounding environment. All of these affect and determine the potential group of re-colonizers in a given post-industrial area. Most research focuses on describing potential plant communities, particularly forests formed on degraded land (7), while there have been few studies concerning recolonization by animals, particularly forest fauna. Research on the rate of recolonization of post-industrial areas by invertebrates has concerned only bees (8), butterflies, leafhoppers (9), spiders (10) and beetles $(10,11)$.

Carabid beetles (Coleoptera Carabidae) have found application, confirmed by numerous studies, as bioindicators of environmental disturbances and as a target for conservation efforts $(12,13)$. As a group whose ecology and taxonomy are well known, characterized by high sensitivity to environmental changes, carabids are often chosen for studies on disturbances, e.g. habitat fragmentation (14), grazing (15), pesticides (16), agriculture (17), forest management (18), inundation (19), urbanization (20), heavy metal concentration $(21,22,23)$ and slag heap restoration (24). In the case of severely degraded post-industrial areas, various elements of the life history of carabids enable them to successfully recolonize the area, and characteristic adaptations constitute an important bioindicator element $(25,26)$. Numerous studies have confirmed that analyses based on elements of the life-history traits of selected organisms are extremely important for restoration projects on fallow land or disfigured post-industrial areas, which would include slag heaps $(27,28,29)$.

In this study we wanted to ask the question if traditional land rehabilitation processes improve habitat quality and function in the forest using ground beetles as indicators. We expected that: (i) Carabid assemblages in areas where restoration procedures were based solely on planting of trees have a similar composition as assemblages in early-successional, unrehabilitated areas. (ii) The distribution of life-history traits of ground beetles on restored slag deposits resembles early-successional stages in which the present species have broad ecological requirements, indicating that the rate of regeneration of the forest ecosystem is very slow.

\section{MATERIALS AND METHODS}

\section{Study Area}

The study was carried out in an industrially degraded area, i.e. a slag heap of post-industrial waste produced by the Skawina Power Plant (Elektrownia Skawina S.A.) in southern Poland (4858'13.7” N, 1946’03.3” E). Com- bustion waste in the form of a mixture of ash and slag had been deposited from 1975 on a slag heap with a total area of 68 ha. After the slag heap was formed and waste deposition ceased in 1995, the slopes of the slag heap were planted with native tree species (birch, poplar, aspen and oak). After exploitation ended in 2010, the unused top of the slag heap was filled in with non-hazardous construction waste (rubble and sand) in order to even out the misshapen surface of the land, which led to spontaneous succession of grasses (Calamagrostis epigeios, Elymus repens and Agrostis gigantea) and herbs (Solidago gigantea, Gallium aparine and Cirsium arvense). The study area comprised surfaces on the slag heap divided into the restored part (the sides, 20 years old, planted with trees) and the unrehabilitated, early-successional top (3-year-old meadow). The reference areas were chosen within a distance of half a kilometre from the slag heap and were of similar age and vegetation composition (trees with dominance of alder, poplar and birch, and meadows with Calamagrostis epigeios and Deschampsia caespitosa). Twenty $50 \times 50 \mathrm{~m}$ research plots were established, evenly distributed on the meadow and forest in the slag and reference areas.

\section{Carabid beetle sampling}

Carabid beetles were caught during the 2012 growing season using pitfall traps. On each of the four types of treatments (slag heap x meadow and forest; and adjacent reference areas $\mathrm{x}$ meadow and forest), five transects were established (Figure 1). The study sites were dispersed randomly across the area, but with the limitations given by the availability of similar habitats. To minimize pseudoreplication arising from the proximity of an identical habitat, slag heap sites were selected close to the reference sites in the same habitat type, but sites within each treatment class were farther apart $\left(\right.$ ANOVA $_{\mathrm{f}_{\text {forest }}}=73.06, \mathrm{p}<0.001$, $\left.\mathrm{F}_{\text {meadow }}=15.12, \mathrm{p}<0.01\right)$. In each transect, 5 traps contain-

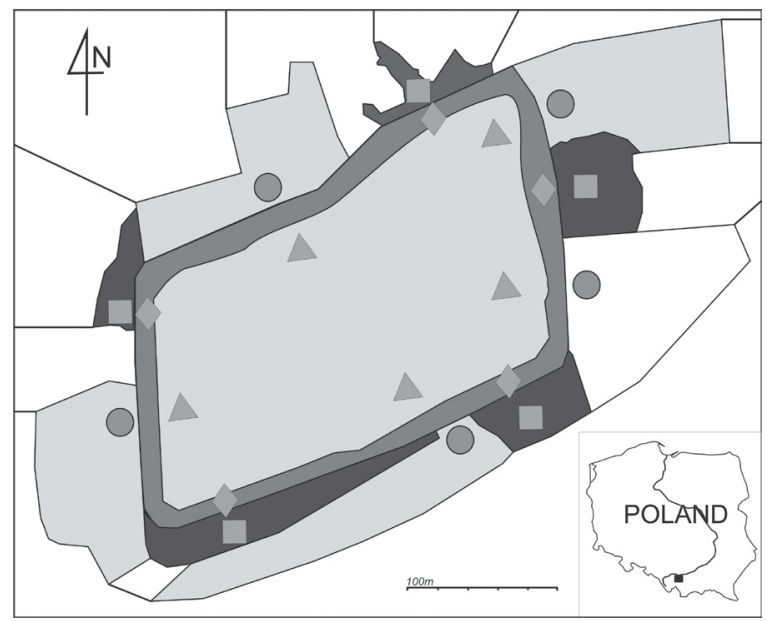

Figure 1. Distribution of sample sites in relation to habitat type (circle-meadow, square-forest, diamond-rehabilitated forest on the slag heap, triangle-unrehabilitated top of the slag heap) 
Table 1. Mean $\pm S D$ content of organic matter, $p H$ and heavy metals in the soil

\begin{tabular}{|c|c|c|c|c|c|c|c|c|}
\hline \multirow{2}{*}{\multicolumn{2}{|c|}{ Sampling plots }} & \multirow{2}{*}{$\begin{array}{c}\text { Organic } \\
\text { matter }[\%]\end{array}$} & \multirow{2}{*}{$\mathrm{pH} \mathrm{H} \mathrm{H}_{2} \mathrm{O}$} & \multirow{2}{*}{$\mathrm{pH} \mathrm{KCl}$} & $\mathrm{Cd}$ & $\mathrm{Pb}$ & $\mathrm{Zn}$ & $\mathrm{Cu}$ \\
\hline & & & & & \multicolumn{4}{|c|}{$\mathrm{mg} \mathrm{kg}^{-1}$} \\
\hline \multirow{4}{*}{ Reference } & \multirow{2}{*}{ Meadow } & 4.55 & 5.83 & 4.65 & 0.25 & 19.25 & 56.75 & 20.75 \\
\hline & & \pm 0.43 & \pm 0.33 & \pm 0.23 & \pm 0.21 & \pm 8.91 & \pm 14.77 & \pm 0.83 \\
\hline & \multirow{2}{*}{ Forest } & 3.50 & 5.30 & 4.35 & 0.59 & 24.10 & 79.50 & 20.18 \\
\hline & & \pm 0.40 & \pm 0.31 & \pm 0 & \pm 0.31 & \pm 5.11 & \pm 10.27 & \pm 20.12 \\
\hline \multirow{4}{*}{ Slag } & \multirow{2}{*}{ Meadow } & 13.40 & 7.20 & 7.03 & 0.29 & 23.23 & 126.75 & 71.88 \\
\hline & & \pm 4.29 & \pm 0.49 & \pm 0.47 & \pm 0.12 & \pm 7.16 & \pm 20.59 & \pm 11.33 \\
\hline & \multirow{2}{*}{ Forest } & 5.78 & 7.63 & 7.30 & 0.32 & 24.90 & 87.25 & 37.13 \\
\hline & & \pm 0.69 & \pm 0.05 & \pm 0.31 & \pm 0.13 & \pm 9.28 & \pm 24.00 & \pm 1.18 \\
\hline
\end{tabular}

ing ethylene glycol solution were set up linearly. The average distance between traps was no more than $10 \mathrm{~m}$. To investigate seasonal variation, the material was collected over the entire growing season from May to October and the pitfall traps were emptied twice a month in two periods (three samples in spring and two in autumn) (30).

\section{Field assessments}

On each type of surface of the study area soil material was collected for determination of the content of heavy metals, content of organic matter, and $\mathrm{pH}$ (Table 1). In the laboratory the soil underwent wet mineralization in a mixture of concentrated acids (nitric and perchloric), and hydrogen chloride was used for extraction of $\mathrm{Cd}, \mathrm{Pb}, \mathrm{Zn}$ and $\mathrm{Cu}$ (31). Content of these trace elements was determined by FAAS in a Solaar M6 Atomic Absorption Spectrometer. Organic matter content was measured by thermogravimetry (31) and $\mathrm{pH}$ in a $\mathrm{KCl}$ suspension by potentiometry. The results obtained indicate low content of heavy metals in the substrate, within standards for soils in Poland, which was rejected as a factor influencing the composition of carabid beetle assemblages (32).

\section{Data analysis}

Principal component analysis was used to estimate the main gradients of environmental factors along 20 sample site transects. Non-metric multidimensional scaling (NMDS) was used to test the relationships between carabid assemblages in different habitat categories (slag heap and habitat type - meadow or forest). The NMDS analysis was performed with WinKyst 1.0 software using the Morisita index as modified by Horn, eliminating the effect of sample size (33). Significance of differences between habitat categories was tested using PERMANOVA analysis followed the Bonferroni correction (34). The percentages of individual species in statistically significant groups were determined by SIMPER analysis (Past for Windows 2.17c) (35). Literature data were used to classify carabid beetles in life-history trait categories on the basis of morpho-physiological and phenological features (36). The fol- lowing life-history traits were analysed: body size (small < $10 \mathrm{~mm}$, medium 10-20 $\mathrm{mm}$ and large $>20 \mathrm{~mm}$ ), feeding strategy (predators or herbivores), breeding type (autumn and spring breeders), wing development (brachypterous or macropterous), and habitat preferences (forest or meadow). Due to right-skewed distribution of abundance in lifehistory trait groups (Shapiro-Wilk test), the relationship of the habitat type and slag heap presence with life-history trait parameters was determined by a generalized linear model for Poisson distributions with the log link function. The differences between means were compared using the multiple Bonferroni comparison test. Both analyses were performed in Statistica for Windows v.10 (37).

\section{RESULTS}

The principal component analysis for environmental factors showed one significant gradient of variables. The first PCA axis described $88.9 \%$ of the total variation in

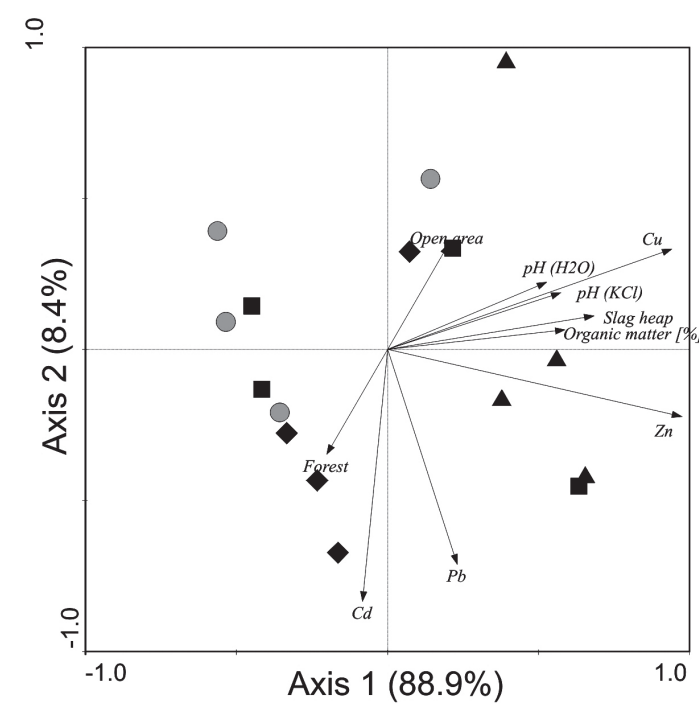

Figure 2. Principal component analysis of environmental data (circle-meadow, square-forest, diamond-rehabilitated forest on the slag heap, triangle-unrehabilitated top of the slag heap) 
the data (Figure 2), clearly dividing slag heap sites from reference sites. The first axis was positively correlated with the following parameters: concentration of zinc (load. 0.97 ) and copper (load. 0.94), content of organic matter (load. 0.57) and $\mathrm{pH}$ (load. 0.57). The second axis, describing only $8.4 \%$ of the total variation, was mainly related to concentration of cadmium (load. -0.83) and lead (load. -0.71 ) and to habitat type - forest or meadow (load -0.34 , $0.34)$. The distribution of the sites showed high variation in environmental parameters between the slag heap and reference sites.

During the field study a total of 1,639 beetles of the carabid family (Coleoptera; Carabidae), belonging to 47 species, were collected. The most abundant species were Harpalus rufipes (accounting for 36\% of all individuals), Poecilus versicolor (20\% of all individuals) and Pterostihus niger ( $7 \%$ of the assemblage). The results of NMDS (stress $=0.1)$ indicated that the species composition of the carabid assemblages was closely related to the type of habitat (meadow or forest) on the reference sites and slag heap (Figure 3). Notably, however, the forest assemblages of the slag heap were not clearly separated from the early successional sites of the slag heap meadow.

The PERMANOVA analysis of the Moristita-Horn distances of similarity showed that the reference assemblages of the meadow and forest areas were statistically significantly different from the assemblages of the slag heap. Within the slag heap itself there was no statistically significant differentiation of the species composition between the early-successional assemblages of the meadow on the top and the forest on the sides, where a rehabilitation procedure involving solely planting of trees was carried out (Table 2).

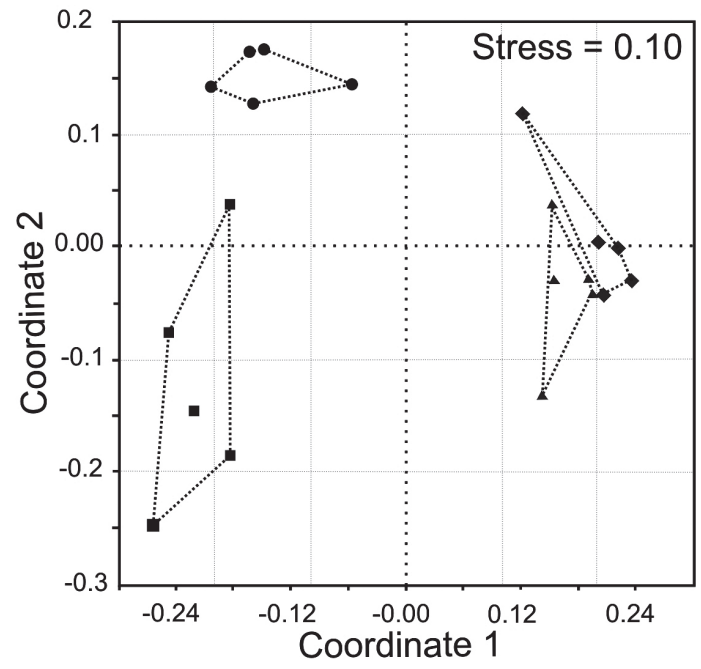

Figure 3. NMDS for ground beetle assemblages in relation to habitat type and slag heap presence (circle-reference meadow, square-reference forest, diamond-slag heap forest, triangle-slag heap meadow)
Table 2. F statistics of PERMANOVA analysis comparing ground beetle variation between habitat types of twenty transects of pitfall traps in four classes $\left({ }^{*} p<0.05\right.$, significance after Bonferroni correction)

\begin{tabular}{|cccccc|}
\hline & & \multicolumn{2}{c}{ Reference } & \multicolumn{2}{c|}{ Slag heap } \\
\hline & & Forest & Meadow & Forest & Meadow \\
\hline \multirow{2}{*}{ Reference } & Forest & - & - & - & - \\
& Meadow & $14.15^{*}$ & - & - & - \\
\multirow{2}{*}{ Slag heap } & Forest & $20.53^{*}$ & $36.26^{*}$ & - & - \\
& Meadow & $26.54^{*}$ & $41.27^{*}$ & 1.1 & - \\
\hline
\end{tabular}

SIMPER analysis, based on the degree of similarity (slag heap meadow and foreset treated as single slag heap assemblage according to PERMANOVA analysis), specified which species have the greatest influence on the occurrence of differences between classes of assemblages (Table 3). In the case of assemblages of the slag heap plots (Slag heap) and the forest the total percentage of dissimilarity, for which ten species were responsible, was $90.4 \%$ (Table 3). Among these only three species (Harpalus rufipes, Poecilus versicolor and Harpalus hirtipes) were present in greater densities on the transformed area of the slag heap (the sides of the slag heap planted with trees). The remaining eight species, including Platynus assimilis, Pterostichus oblongopunctatus, Pterostichus niger, Carabus granulatus and Carabus ulrichii, clearly preferred the reference forest areas. In the case of the slag heap plots (Slag heap) and the reference meadows (Meadow), the total percentage of dissimilarity was $92.1 \%$ (Table 3 ).

SIMPER analysis made it possible to identify the species which were the main dominants on the severely transformed and disturbed slag heap in comparison with the reference areas. A total of 15 species were responsible for this distribution, among which Harpalus rufipes and Harpalus hirtipes were clearly dominant in the slag heap area in both habitat types (forest and meadow). The remaining species, including Poecilus versicolor, Pterostichus niger, Carabus cancellatus, Carabus granulatus, Oodes helopioides and Bembidion guttula, were more abundant in the reference meadow habitats.

The generalized linear model showed a significant influence of the slag heap itself or in combination with habitat type on the abundance of all individual carabid life-history traits (Table 4).

The distribution of abundances in three body-size classes in relation to habitat type and slag heap presence showed that large ground beetles are significantly eliminated from the slag heap in both meadow and forest habitats (Figure 4). Multiple Bonferroni comparison showed strong separation of large species between slag heap and reference sites. In the case of the medium and 
Table 3. Simper analysis for the ground beetles species contributing more than 1\% to the dissimilarity between slag heap and reference forest and meadow assemblages. The colour grey indicates higher abundance in slag heap assemblages and white indicates higher abundance in reference assemblages.

\begin{tabular}{|c|c|c|c|c|}
\hline Taxon & $\begin{array}{c}\text { Mean abundance } \\
\text { (Forest) }\end{array}$ & $\begin{array}{l}\text { Mean abundance } \\
\text { (Slag heap) }\end{array}$ & $\begin{array}{c}\text { Average } \\
\text { dissimilarity }\end{array}$ & $\begin{array}{c}\text { Contribution } \\
(\%)\end{array}$ \\
\hline \multicolumn{5}{|l|}{ Forest - slag heap } \\
\hline Harpalus rufipes (De Geer, 1774) & 0.8 & 57.1 & 38.5 & 41.4 \\
\hline Poecilus versicolor (Sturm, 1824) & 3.2 & 3.3 & 3.8 & 4.1 \\
\hline Harpalus hirtipes (Panzer, 1796) & 0.0 & 1.8 & 1.8 & 1.9 \\
\hline Platynus assimilis (Paykull, 1790) & 14.6 & 0.0 & 11.1 & 11.9 \\
\hline Pterostichus oblongopunctatus (Fabricius, 1787) & 11.0 & 0.3 & 9.0 & 9.7 \\
\hline Pterostichus niger (Schaller, 1783) & 8.0 & 0.9 & 5.6 & 6.0 \\
\hline Carabus granulatus Linné, 1758 & 6.0 & 0.2 & 5.1 & 5.5 \\
\hline Carabus ulrichii Germar, 1824 & 5.2 & 0.4 & 4.4 & 4.8 \\
\hline Carabus cancelatus Illiger, 1798 & 3.2 & 0.4 & 2.6 & 2.8 \\
\hline Pterostichus nigrita (Paykull, 1790) & 2.6 & 0.0 & 2.1 & 2.3 \\
\hline \multicolumn{5}{|l|}{ Meadow - slag heap } \\
\hline Harpalus rufipes (De Geer, 1774) & 3.2 & 57.1 & 23.0 & 26.1 \\
\hline Harpalus hirtipes (Panzer, 1796) & 0.6 & 1.8 & 1.0 & 1.1 \\
\hline Poecilus versicolor (Sturm, 1824) & 55.0 & 3.3 & 25.5 & 29.0 \\
\hline Pterostichus niger (Schaller, 1783) & 13.4 & 0.9 & 6.9 & 7.9 \\
\hline Carabus cancelatus Illiger, 1798 & 11.8 & 0.4 & 6.1 & 7.0 \\
\hline Carabus granulatus Linné, 1758 & 6.4 & 0.2 & 2.8 & 3.2 \\
\hline Oodes helopioides (Fabricius, 1792) & 6.0 & 0.0 & 2.8 & 3.1 \\
\hline Bembidion guttula (Fabricius, 1792) & 5.4 & 0.0 & 3.2 & 3.6 \\
\hline Carabus ulrichii Germar, 1824 & 4.8 & 0.4 & 2.3 & 2.6 \\
\hline Amara curta Dejean, 1828 & 3.2 & 0.5 & 1.7 & 1.9 \\
\hline Poecilus cupreus (Linné, 1758) & 2.6 & 0.5 & 1.2 & 1.4 \\
\hline Pterostichus strenuus (Panzer, 1796) & 2.2 & 0.0 & 1.2 & 1.3 \\
\hline Harpalus affinis (Schrank, 1781) & 2.0 & 0.6 & 1.3 & 1.5 \\
\hline Dyschirius globosus (Herbst, 1784) & 2.0 & 0.0 & 1.0 & 1.2 \\
\hline Clivina fossor (Linné, 1758) & 1.8 & 0.0 & 1.0 & 1.2 \\
\hline
\end{tabular}

small body-size classes, this relationship is not specific and habitat-dependent.

The abundance of predators showed a similar pattern as in the case of the large body-size class (Figure 5). In the case of herbivores, however, an increase in mean abundance was observed on slag heap meadow sites. Significantly more herbivores were observed in forest habitats than on slag heap sites. A significant negative effect on autumn breeding species was observed on both slag heap habitats, while spring breeders were much more habitatdependent (Figure 6).

The variation in brachypterous species with low dispersal power was also slag-heap-dependent, but surprisingly there was no significant difference in abundance between habitat types on either the slag heap or the reference sites. The abundance of macropterous beetles was significantly increased by the early colonization of the meadow on the top of the slag heap (Figure 7). The distribution of habitat specialists among the slag heap and reference sites was also unusual (Figure 8). Forest specialist distribution depended negatively on the slag heap. Meadow specialists were much more habitat-dependent. The slag heap negatively influenced forest specialists, while habitat type had a pronounced effect on meadow specialists.

\section{DISCUSSION}

First we wanted to establish whether adjacent areas affect the composition of ground beetles. The study sites on the slag heap meadows and forest were not spatially correlated. The average distance between slag heap transects was significantly higher than their distance to the reference sites (Figure 1). Therefore we can exclude the effect of spontaneous succession from reference sites to forested slopes to the meadow at the top. If the colonization direction are correct, we should then expect close relationships between the reference forest and adjacent slag heap forest. There was no barrier between these hab- 
Table 4. GLM (Wald statistics) for changes in life-history trait distribution in relation to slag heap presence and habitat type (forest - meadow) $\left({ }^{*} p<0.05,{ }^{* *} p<0.001,{ }^{* * *} p<0.0001\right)$

\begin{tabular}{|c|c|c|c|c|}
\hline \multicolumn{2}{|c|}{ Life-history traits } & Slag heap & Habitat type & Slag heap * Habitat type \\
\hline \multirow{3}{*}{ Body size } & Large & $71.36^{* * *}$ & 2.18 & $8.93^{*}$ \\
\hline & Medium & 1.64 & $271.57^{* * *}$ & $11.38^{* *}$ \\
\hline & Small & $30.37^{* * *}$ & $8.57^{*}$ & $4.39^{*}$ \\
\hline \multirow{2}{*}{ Feeding strategy } & Predators & $387.25^{* * *}$ & $13.36^{* *}$ & $4.37^{*}$ \\
\hline & Herbivores & $131.91^{* * *}$ & $75.18^{* * *}$ & $7.43^{* *}$ \\
\hline \multirow{2}{*}{ Breeding type } & Autumn & $22.47^{* * *}$ & 3.78 & $7.43^{*}$ \\
\hline & Spring & $30.42^{* * *}$ & $308.04^{* * *}$ & $10.40^{*}$ \\
\hline \multirow{2}{*}{ Wing development } & Brachypterous & $48.27^{* * *}$ & 3.68 & $12.26^{* *}$ \\
\hline & Macropterous & $4.38^{*}$ & $294.70^{* * *}$ & $9.06^{*}$ \\
\hline \multirow{2}{*}{ Habitat } & Forest & $163.51^{* * *}$ & $9.37^{* *}$ & 0.26 \\
\hline & Open & $42.73^{* * *}$ & $413.24^{* * *}$ & $40.49^{* * *}$ \\
\hline
\end{tabular}

itats and species should have been able to migrate very freely. There were no differences with respect to habitat conditions, such as heavy metal concentrations or $\mathrm{pH}$ (Figure 2). The reference forest was formed as a result of spontaneous secondary succession, while the slag heap forest was planned de novo on newly established ground. Communities of slag heap forest differ from those of the reference sites despite 20 years of rehabilitation. NMDS analysis confirmed by PERMANOVA revealed differences in carabid species composition on the degraded slag heap with respect to the reference plots, but showed no significant differences between the early-successional meadow of the slag heap and its forested sides (Figure 3), which underwent restoration about 20 years ago. Afforestation should disrupt the characteristic ground beetle communities of these open-character habitats (38). A drastic change in ground beetle communities in concert with canopy closure 20-30 years after clear-cutting was observed by Koivula et al (39). Clear differences in both species list and assemblage composition between young, open succession stages and older stages with taller trees and closed canopy have been observed (40). A long-time effect on regeneration of ground beetle assemblages has been observed in several studies of forest regeneration after clear-cutting (41). These results showed that the restoration process is very slow, even if the adjacent area is a source of colonizers allowing rapid and successful recreation of ground beetle forest assemblages.

In each of the systems studied it was possible to distinguish species that react positively or negatively to a particular type of habitat (Table 3). In the slag heap area there were species whose abundance was much higher than in the reference areas, belonging to the genus Harpalus. This was true of both open and reforested areas. A characteristic trait of species of this genus is their high degree of dietary flexibility and their ability to feed on plant material. The occurrence of these species on the slag heap is indicative of a specific type of response of carabid assemblages to environmental disturbances. Species properties such as food requirements respond to environmental changes (42). High abundance of Harpalus species and a reduction in the mean abundance of Carabus and Pterostichus predators indicate a decrease in food capacity in the environment of the slag heap. The main food source for
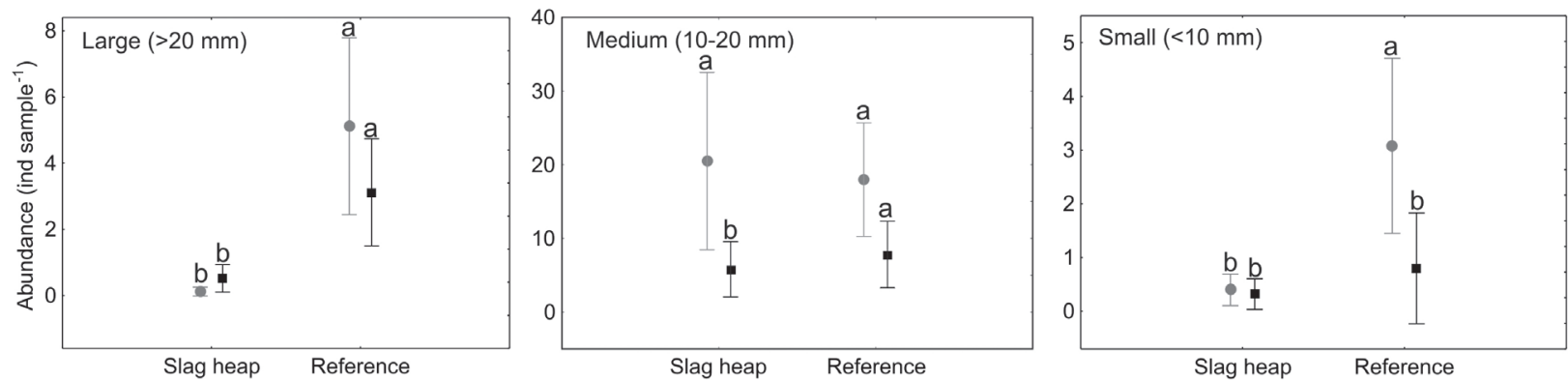

Figure 4. Average abundance of ground beetle body-size classes in two habitat types - forest (square) and meadow (circle) of slag heap and reference sites. Different letters indicate significant differences between treatments. Multiple comparisons of means were performed using the Bonferroni test at 0.05 significance. 

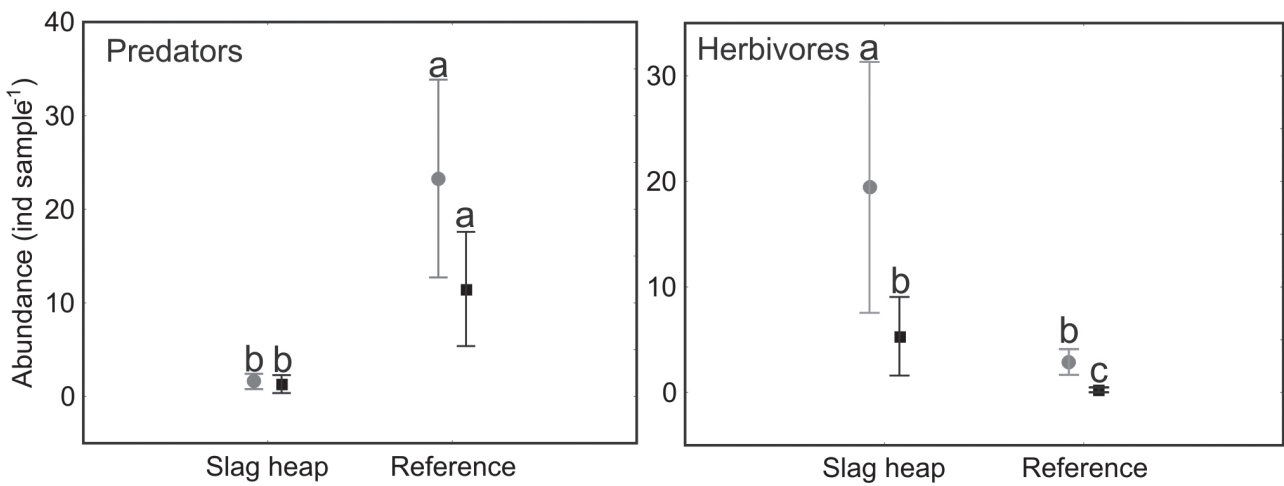

Figure 5. Average abundance of ground beetles with different food preferences recorded in slag heap and reference sites of two habitat types: forest (square) and meadow (circle). Different letters indicate significant differences between treatments. Multiple comparisons of means were performed using the Bonferroni test at 0.05 significance.
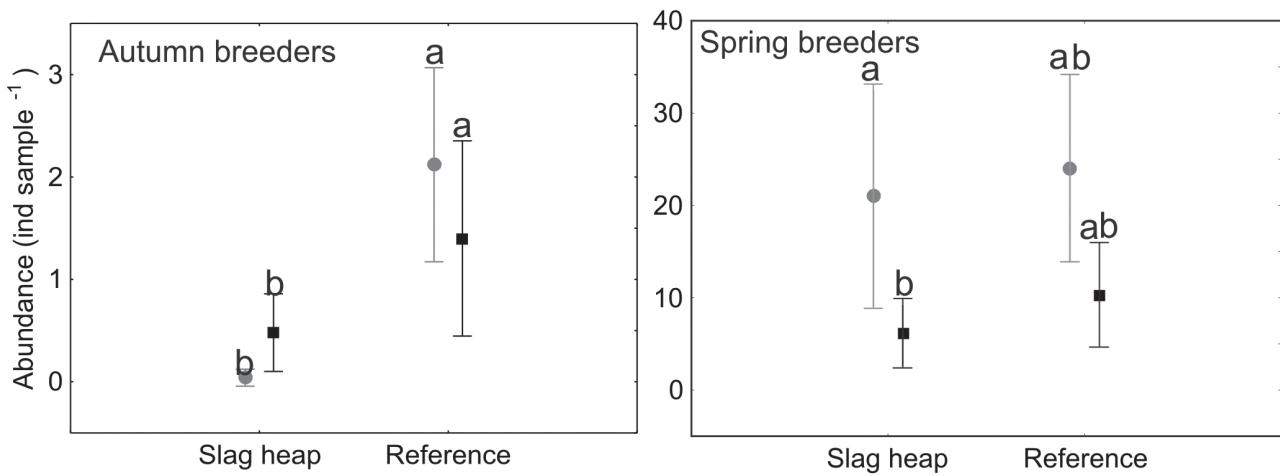

Figure 6. Average abundance of ground beetles with different breeding types recorded in slag heap and reference sites two habitat types: Forest (square) and meadow (circle). Different letters indicate significant differences between treatments. Multiple comparisons of means were performed using the Bonferroni test at 0.05 significance.

these predators is earthworms and springtails (43). Abundance and total biomass of earthworms significantly decrease in post-industrial areas without reclamation of the soil $(44,45)$. Therefore the dominance of herbivorous ground beetles is a consequence of food limitation in soil fauna (earthworms and springtails as detritivores) and thus the absence of fundamental processes associated with decomposition and the proper functioning of ecosystems (2).

The poor conditions in the slag heap forest are confirmed by carabid life-history trait distribution. Elements of life history are strongly dependent on the environment. Habitat is a fundamental selective factor for species with defined life-history traits $(10,46)$. The slag heap assemblages consisted mainly of species having broad ecological requirements. The most notable feature of the distribution of carabid life-history traits on the slag heap is the reduction in abundances of such groups as large and small predators having an autumn breeding type of reproduction, with limited dispersal abilities and preferring forests. In all of these groups abundance was significantly lower in slag heap habitats than on reference sites (Figures 4-7).
Surprisingly, rehabilitation procedures in slag heap areas had no significant effect in any of these groups.

Many authors link body-size distribution of beetles with the intensity of the disturbance $(10,21,36,47)$. Large carnivores are more sensitive to disturbance then smaller ones. This is confirmed by the fact that abundance of large carnivores was higher in reference assemblages than in slag heap assemblages (Figure 4). However, the distribution of large beetles between the rehabilitated forest on the slag heap and the unrehabilitated early-successional meadow does not confirm this hypothesis.

We should then expect many more large carabids in the slag heap forest than in the reference meadow, but this was not confirmed, indicating the presence of similar unfavourable conditions at the rehabilitated and unrehabilitated sites. We should also expect many more smallsized beetles in the slag heap areas than in reference sites. However, the body-size hypothesis should not be applied more generally to food availability. In the case of slag assemblages, small-bodied species are predators and rely on distribution of food resources. The abundance of preda- 

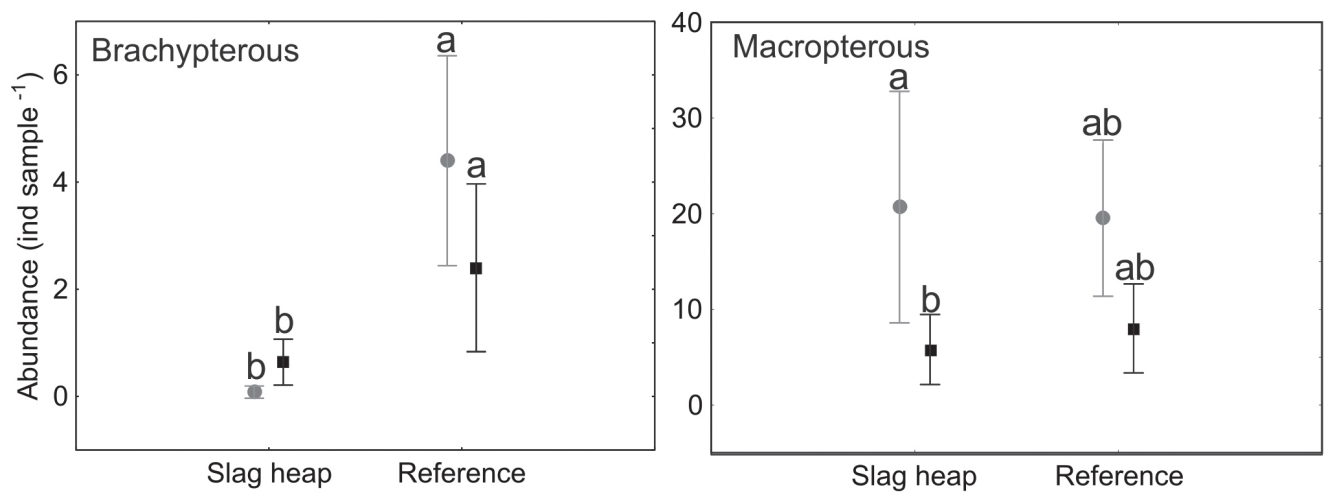

Figure 7. Average abundance of ground beetle habitat specialists recorded in slag heap and reference sites of two habitat types: forest (square) and meadow (circle). Different letters indicate significant differences between treatments. Multiple comparisons of means were performed using the Bonferroni test at 0.05 significance.
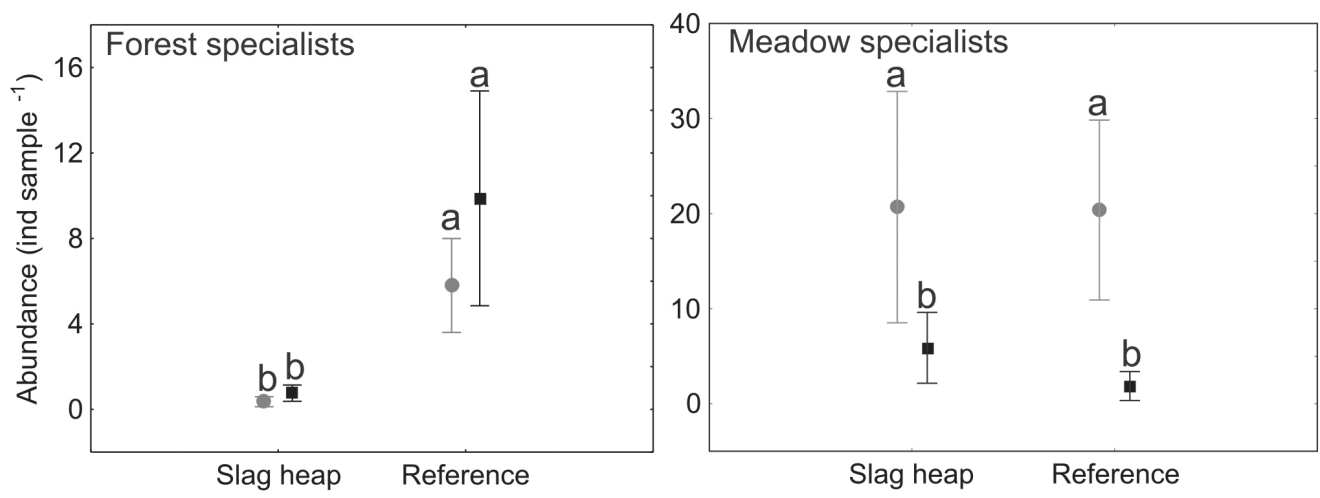

Figure 8. Average abundance of ground beetles of different dispersal abilities recorded in slag heap and reference sites of two habitat types: forest (square) and meadow (circle). Different letters indicate significant differences between treatments. Multiple comparisons of means were performed using Bonferroni test at 0.05 significance.

tors was significantly lower on slag heap areas (Figure 5). On the slag heap where the soil was not rehabilitated, large and small-sized species were eliminated, which might be explained by prey limitation (mainly earthworms) in both slag heap habitat types.

Dispersal power is another life-history trait which, like feeding strategy and body size, is dependent on the intensity of disturbances. Abundance of macropterous ground beetles usually increases along a gradient of habitat disturbance intensity $(31,36)$. New colonizers are mostly winged, which allows them to colonize new habitats very rapidly after environmental conditions have stabilized (19). The abundance of carabids with low dispersal power (brachypterous) significantly decreases on slag heap forest and meadows (Figure 7). If the slag forest is more stable than the meadow on the top of the slag heap, we should have significantly more brachypteres on rehabilitated sites. Their very low abundance in the slag heap forest may indicate inadequate resources crucial for carabid development, due in part to unsuccessful rehabilitation procedures. Our study than indicates that land rehabilitation procedures involving only tree plantation are incapable of restoring ecosystems functioning. In the case of the slag heap forest the substrate was not rehabilitated with respect to soil organisms. The process of recolonization by soil organisms is extremely slow and does not change even after 100 years of regeneration (33). Hence the main consequence of rehabilitation do not allow a rapid enrichment of the soil fauna, which is the source of food for carabid beetles.

Severely degraded post-industrial areas cause severe disturbances not only at the level of the landscape but also in the functioning of entire ecosystems $(44,48)$, causing irreversible changes (7). A variety of land rehabilitation techniques are used to restore the natural biological diversity of these areas $(9,33,44)$ and their effects depend on numerous factors, including the degree of degradation of the land, the water regime, and soil properties (3). Without restoration of the soil, ecosystems cannot function properly $(13,33)$. The importance of soil properties has been underscored in numerous studies as a factor shaping the diversity of ground-dwelling fauna (including carabids), as well as the rate of succession $(18,29,33)$. Of 
particular importance for carabids is the surface layer of the soil, rich in litter (32) and organic matter (8), where fluctuations in temperature are smaller, moisture and developmental conditions are better, and food is more available (47). Elimination or disturbance of this important habitat element leads to the disappearance and replacement of many species of ground-dwelling specialists by generalists (22). Future studies should be performed to investigate the role of different soil elements and soil rehabilitation in ecosystem rehabilitation of slag heaps.

Acknowledgements: The authors thank Marek Telk for laboratory assistance. This research was supported by Research Project BM 4345/KEKiOP/2014 financed by the Agriculture University of Cracow.

\section{REFERENCES}

1. KERR JT, CURRIE DJ 1995 Effects of Human Activity on Global Extinction Risk. Conservation Biology 9: 1528-1538 http://dx.doi.org/10.1046/j.1523-1739.1995.09061528.x

2. HEDDE M, VAN OORT F, LAMY I 2012 Functional traits of soil invertebrates for exposure to soil disturbance. Environmental Pollution 164: 59-65 http://dx.doi.org/10.1016/j.envpol.2012.01.017

3. TOPP W, THELEN K, KAPPES H 2010 Soil dumping techniques and afforestation drive ground-dwelling beetle assemblages in a 25 -year-old open-cast mining reclamation area. Ecological Engineering 36: 751-756 http://dx.doi.org/10.1016/j.ecoleng.2009.12.011

4. ZIPPER CE, BURGER JA, SKOUSEN JG, ANGEL PN, BARTON CD, DAVIS V, FRANKLIN JA 2011 Restoring Forests and Associated Ecosystem Services on Appalachian Coal Surface Mines. Environmental Management 47: 751-765 http://dx.doi.org/10.1007/s00267-011-9670-z

5. BURGER JA, GRAVES D, ANGEL P, DAVIS V, ZIPPER C 2005 The forestry reclamation approach. Appalachian Regional Reforestation Initiative, US Office of Surface Mining. Forest Reclamation Advisory Number 2

6. PEY B, NAHMANI J, AUCLERC A, CAPOWIEZY, CLUZEAU D, CORTET J, DECAËNS T, DEHARVENG L, DUBS F, JOIMEL S, BRIARD C, GRUMIAUX F, LAPORTE MA, PASQUET A, PELOSI C, PERNIN C, PONGE JF, SALMON S, SANTORUFO L, HEDDE M 2014 Current use of and future needs soil invertebrate functional traits in community ecology. Basic and Applied Ecology 15: 194-206 http://dx.doi.org/10.1016/j.baae.2014.03.007

7. MORENO-DE LAS HERAS M, NICOLAU JM, ESPIGARES T 2008 Vegetation succession in reclaimed coal-mining slopes in a Mediterranean-dry environment. Ecological Engineering 34: 168-178 http://dx.doi.org/10.1016/j.ecoleng.2008.07.017

8. TROPEK R, CERNA I, STRAKA J, CIZEK O, KONVICKA M 2013 Is coal combustion the last chance for vanishing insects of inland drift sand dunes in Europe? Biological Conservation 162: 60-64 http://dx.doi.org/10.1016/j.biocon.2013.03.027

9. TROPEK R, KADLEC T, KAREŠOVA P, SPITZER L, KOČAREK P, MALENOVSKY I, BAŇǍ̌ P, TUF IH, HEJDA M, KONVIČKA M 2010 Spontaneous succession in limestone quarries as an effective restoration tool for endangered arthropods and plants. Journal of Applied Ecology 47: 139-147 http://dx.doi.org/10.1111/j.1365-2664.2009.01746.x

10. PEDLEY SM, DOLMAN PM 2014 Multi-taxa trait and functional responses to physical disturbance. Journal of Animal Ecology 83: 1542-1552 http://dx.doi.org/10.1111/1365-2656.12249
11. SKALSKI T, POŚPIECH N 2006 Beetles community structures under different reclamation practices. European Journal of Soil Biology 42: 317-320 http://dx.doi.org/10.1016/j.ejsobi.2006.07.026

12. KOIVULA MJ 2011 Useful model organisms, indicators, or both? Ground beetles (Coleoptera, Carabidae) reflecting environmental conditions. Pages 287-317 In: Kotze D.J., Assmann T., Noordijk J., Turin H., Vermeulen R. (eds.). Carabid beetles as bioindicators: biogeographical, ecological and environmental studies. ZooKeys 100 http://dx.doi.org/10.3897/zookeys.100.1533

13. SKALSKI T, KĘDZIOR R, WYŻGA B, RADECKI-PAWLIKA, PLESIŃSKI K, ZAWIEJSKA J 2016 Impact of incision of gravelbed rivers on ground beetle assemblages. River Research and Applications http://dx.doi.org/10.1002/rra.3027

14. NIEMELÄ J 2001 Carabid beetles (Coleoptera: Carabidae) and habitat fragmentation: a review. European Journal of Entomology 98: 127-132 http://dx.doi.org/10.14411/eje.2001.023

15. GRANDCHAMP AC, BERGAMINI A, STOFER S, NIEMELA J, DUELLI P, SCHEIDEGGER C 2005 The influence of grassland management on ground beetles (Carabidae, Coleoptera) in Swiss mountain meadows. Agriculture, Ecosystems and Environment 110: 307-317 http://dx.doi.org/10.1016/j.agee.2005.04.018

16. HOLLAND JM, LUFF ML 2000 The effects of agricultural practices on Carabidae in temperate agroecosystems. Integrated Pest Management Reviews 5: 109-129 http://dx.doi.org/10.1023/A:1009619309424

17. KOSEWSKA A, SKALSKI T, NIETUPSKI M 2014 Effect of conventional and non-inversion tillage systems on particular life traits carabid beetles (Coleoptera, Carabidae) occurring in the cultivation of winter triticale. European Journal of Entomology. European Journal of Entomology 111: 669-676

18. SKŁODOWSKI J 2014a Effects of top-soil preparation and broadleaved tree mixture on carabid beetles in afforested fallow plots. Restoration Ecology 22: 13-21 http://dx.doi.org/10.1111/rec.12034

19. SKALSKI T, KĘDZIOR R, RADECKI-PAWLIK A 2012 Riverine ground beetles as indicators of inundation frequency of mountain stream: a case study of the Ochotnica Stream, Southern Poland. Baltic Journal of Coleopterology 12: 117-126

20. MAGURA T, LÖVEI GL, TÓTHMÉRÉSZ B 2010 Does urbanization decrease diversity in ground beetle (Carabidae) assemblages? Global Ecology and Biogeography 19:16-26 http://dx.doi.org/10.1111/j.1466-8238.2009.00499.x

21. SKALSKI T, KRAMARZ P, LASKOWSKI R, STONE D 2010 Ground beetle community responses to heavy metal pollution. Baltic Journal of Coleopterology 10: 1-12

22. SKALSKI T, KEDZIOR R, KOLBE D, KNUTELSKI S 2015a Different responses of epigeic beetles to heavy metal contamination depending on functional traits at the family level. Baltic Journal of Coleopterology 15: 81-90

23. SKALSKI T, KĘDZIOR R, KOLBE D, KNUTELSKI S 2015b Biegaczowate jako wskaźniki zanieczyszczenia lasów metalami ciężkimi. Sylwan 159: 905-911

24. KEDZIOR R, SKALSKI T, SZWALEC A, MUNDAŁA P 2014 Diversity of carabid beetle assemblages (Coleoptera, Carabidae) in a post-industrial slag deposition area. Baltic Journal of Coleopterology 14: 219-228

25. EVERSHAM BC, ROY DB, TELFER MG 1996 Urban, industrial and other manmade sites as analogues of natural habitats for Carabidae. Annales Zoologici Fennici 33: 149-156

26. GOEDE RGM, VAN DIJK THS 1998 Establishment of Carabid beetle and nematode populations in a nature restoration project after the abandonment of arable land. Applied Soil Ecology 9: 355-360 http://dx.doi.org/10.1016/S0929-1393(98)00089-4

27. BOWIE M H, FRAMPTON C M 2004 A practical technique for nondestructive monitoring of soil surface invertebrates for eco- 
logical restoration programs. Ecological Management \& Restoration 5: 34-43 http://dx.doi.org/10.1111/j.1442-8903.2004.00171.x

28. LIU Y, AXMACHER JC, WANG C, LI L, YU Z 2012 Ground Beetle (Coleoptera: Carabidae) Assemblages of Restored Seminatural Habitats and Intensively Cultivated Fields in Northern China. Restoration Ecology 20: 234-239 http://dx.doi.org/10.1111/j.1526-100X.2010.00755.x

29. PRACH K, HOBBS RJ 2008 Spontaneous succession versus technical reclamation in the restoration of disturbed sites. Restoration Ecology 16: 363-366

http://dx.doi.org/10.1111/j.1526-100X.2008.00412.x

30. DUELLI P, OBRIST MK 2003 Biodiversity indicators: the choice of values and measures. Agriculture, Ecosystems and Environment 98: 87-98 http://dx.doi.org/10.1016/S0167-8809(03)00072-0

31. OSTROWSKA A, GAWLIŃSKI S, SZCZUBIAŁKA Z 1991 Metody analizy i oceny właściwości gleb i roślin. Instytut Ochrony Środowiska. Warszawa

32. Directive of the Minister of the Environment of 9 September 2002 on soil quality standards and land quality standards, Dz. U. [Journal of Laws] no. 165, item 1.359

33. WOLDA H 1981 Similarity Indices, Sample Size and Diversity. Oecologia 50: 296-302 http://dx.doi.org/10.1007/bf00344966

34. ANDERSEN MJ 2001 A new method for non-parametric multivariate analysis of variance. Austral Ecology 26: 32-46

35. HAMMER $\varnothing$, HARPER DAT, RYAN PD 2001 Past: Paleontological Statistics Software Package for Education and Data Analysis. Palaeontologia Electronica 4: 9

36. SKALSKI T, GARGASZ K, LASKOWSKI R 2011 Does mixed diffuse pollution decrease ground beetle diversity? Baltic Journal of Coleopterology 11: 1-15

37. STATSOFT 2010 STATISTICA (data analysis software system), version 10.0. www.statsoft.com

38. BUTTERFIELD J, LUFF ML, BABES M, EYRE MD 1995 Carabid beetle communities as indicators of conservation potential in upland forests. Forest Ecology and Management 79: 63-77 http://dx.doi.org/10.1016/0378-1127(95)03620-2
39. KOIVULA M, KUKKONEN J, NIEMELÄ J 2002 Boreal carabid beetle (Coleoptera, Carabidae) assemblages along the clear-cut originated succession gradient. Biodiversity and Conservation 11: 1269-1288 http://dx.doi.org/10.1023/A:1016018702894

40. NIEMELÄ J, HAILA Y, PUNTTILA P 1996 The importance of small scale heterogeneity in boreal forests: variation in diversity in forest-floor invertebrates across the succession gradient. Ecography 19: $352-368$ http://dx.doi.org/10.1111/j.1600-0587.1996.tb01264.x

41. MAGURA T, TÓTHMÉRÉSZ B, MOLNÁR T 2000 Spatial distribution of carabids along grass-forest transects. Acta Zoologica Academiae Scientiarum Hungaricae 46:1-17

42. SOUTHWOOD TRE 1977 Habitat, Template for Ecological Strategies. Journal of Animal Ecology 46: 337-365 http://dx.doi.org/10.2307/3817

43. HENGEVELD R 1980 Qualitative and quantitative aspects of the food of ground beetles (Coleoptera, Carabidae): a review. Netherlands Journal of Zoology 30: 555-563 http://dx.doi.org/10.1163/002829679X00188

44. FROUZ J, ELHOTTOVÁ D, KURÁŽ V, ŠOURKOVÁ M 2006 Effects of soil macrofauna on other soil biota and soil formation in reclaimed and unreclaimed post mining sites: Results of a field microcosm experiment. Applied Soil Ecology 33: 308-320 http://dx.doi.org/10.1016/j.apsoil.2005.11.001

45. POŚPIECH N, SKALSKI T 2006 Factors influencing earthworm communities in post-industrial areas. European Journal of Soil Biology 42: 191-199 http://dx.doi.org/10.1016/j.ejsobi.2006.07.015

46. VIOLLE C, NAVAS ML, KAZAKOU ECF, HUMMEL I, GARNIER E 2007 Let the concept of trait be functional. Oikos 116: 882-892 http://dx.doi.org/10.1111/j.0030-1299.2007.15559.x

47. SKŁODOWSKI J 2014b Consequence of the transformation of a primeval forest into a managed forest for carabid beetles (Coleoptera: Carabidae) - a case study from Białowieża (Poland). European Journal of Entomology 111: 639-648 http://dx.doi.org/10.14411/eje.2014.088

48. ZAJAC E, ZARZYCKI J 2012 Revegetation of reclaimed soda waste dumps: Effects of topsoil parameters. Journal of Elementology 17: 525-536 http://dx.doi.org/10.5601/jelem.2012.17.3.14 